Pharmacia Fine Chemicals AB, the manufacturers of 'Sephadex', but is merely a reflexion of the domination of the market by this product. Although any reference work on biochemical techniques must contain a chapter on gel chromatography, this book, which is the most expensive of the trio, must be considered a poor investment because it contains little more informution than can be obtained from the technical literature provided free by the manufacturers of these materials.

The third book describes the uses of inmunochemistry for the identification of various macromolecules, for example, polysaccharides, proteins und lipids. 'The author follows the pattern set by the other two books and concentrates upon the practical applications of the iechniquo and, in particular, pointing out to the reader the possible errors and misinterpretations which can arise. It is pleasantly free from the bewildering terminology which many anthors in this field use with reckless abandon and which may have previously discouraged potential users of this valuable technique.

All three books are printell on good quality paper; they are easy to read and should stand up reasonably well to the constant handling a laboratory manual will inevitably receive. The title on the spine of my volume on immunochemistry contained a glaring error-... 'macromoleculse'.

X. SHAw

\section{CONSTITUENTS OF LICHENS}

\section{Chemical and Botanical Guide to Lichen Products}

By Chicita F. (ulberson. Pp. xi +623. (University of North (arolina Press: Chapel Hill, November 1969.) $\$ 12.50$.

Thrs is a good book which will probably be the standard text on the subject for some time to come. Lichens produce a wide range of compounds which have been variously called lichen acids, lichen substances or lichen products. They include depsides, depsidones, dibenzofurans, usnic acids, chromones, xanthonos, anthraquinones, carotenes, sterols, terpenes, terphenylquinones and pulvinic acid derivatives. Many of these compounds are known only from lichens, particularly those which are acetate-polymalonate derived aromatic phenols joined by esterification, oxidative coupling or both.

'Two quite different, groups of scient ists are interested in these compounds. First, and for obrions reasons, thre are organic chemists. Second, there are lichen taxonomists. It is over a century since Nylander described the "eolour tests" which became an integral part of the identification and classification of lichens. In recent decades, tho development of simple micruchemical methods for the identification of sperific compounds has had a major impact on liehen taxonomy. Indered, in the taxonomy of no other group of plants has chemistry been used so suecessfully as in lichens.

'This book is good because it catcrs so well for both the cherrist and the lichen taxonomist. Dr Culberson herself is an organic chemist with an eminently well deserved reputation in the chernistry of lichen products. Slue has been closely associated in her work with her husband, a lichenologist who is the leading expert in the world in the chemical taxonomy of lichens. Hence, the lichen uomenclature in this book is modern and reliablo, with the synonymy thoroughly checked.

The essential core of the book consists of two major referenee sections. The first lists anore than 300 chemical constituents of lichens, with physical data, chemical structures and annotated referenees. The second lists the oceurrence of these compounds in approximately 2,000 species, forms and varieties of lichens. There is itso ant excellent chapter on the biogenesis of lichen produets and their relationship to the products of freo-living fungi. In dealing witl the chemical constituents, the author has not restricted herself to secondary products or lichen acids, but she also includes carbohydrates, amino-acids, vitamins and growth factors.

Some lichen taxonomists might have appreciated an introductory guide to tho actual methods of using microchemical techniques, although copious references on them are givon. Likewise, the chemist might havo been given some guide as to what compounds might be expected in previously unstudied lichens, especially where primury metabolites aro concerned.

Perhaps the most important comment I can make, however, is an earnest wish that the author and publishers will be able' to produce new editions of this book when advances in research make this necessary.

D. C. SinITII

\section{GROWING VASCULAR CELLS}

\section{Tissue Cultures}

By O. J. Pollak. (Monographs on Atheroselerosis, Vol. 1.) Pp. xii + 143. (Karger: Basle and New York, 1969.) SFr./JM $41 ; 82$.

A Monograph on tissue culture might seem to be an umusual start for a series devoted to atherosclerusis. Workers in the field will, however, appreciate tho need for a fundamental study of the prime reactor in the atherosclerotic process, namely, the vascular endothelial cell.

Tho book is comprehensive and has a full bibliography. It emphasizes and summarizos tho many difficult problems encountered when carrying out and interpreting experiinents with growing vascular colls. Not the least of these problems is the precise identity of the cell that emerges in the course of tissue culture; a problem that is still not entirely solved. A more intensive eytochemical study of such cells might be of value in establishing cell identity; the enthor discusses and emphusizes cytochemical techniques as applied to tissue culture.

Much of the work that is deseribed is concerned with nortic endothelial cells. It does not necessarily follow that they resomble the lining cells of coronary arteries that have not been so fully studied. This imprortant point is made, but perhaps not forcibly enough.

The end of the book is better than the beginning. 'Towards the end there is more discussion and critical comment. The beginning is more of a list of results and names of authors with little or no commentary on thes quality or significance of the reported works.

It is sometimess difficult to understand the meinning of sentences largely because of the Anerican use of English, but generally spealking the subject is clearly and concisely expressed.

This book provides a rare, valuable summary of modern work on arterial cell culture and is an important addition to the witings about atherogenesis. G. A. GReshalr

\section{Obituaries}

\section{Dr G. D. Greville}

Gur D. Grevilte, who died on December 13, 1969, at the age of 62 , had been head of the Departinent of Biochemistry at the Agricultural Research Council Institute of Animal Physiology, Babraham, Cambridge, where he suecerded Sir Rudolph Peters in 1959. Aftel gradunting with a double first in chemistry at Cumbridge? in 1929, he worked for some years in the biochemical section of the Middlesex Hospital Medical School, where he collaborated with F. Dickens and E. C. Dodds. In 1937 he was appointed research bioehemist in charge of the biochemical lahoratories at Runwell Hospital, Essex, 
and in 1944 joined the Ministry of Supply team, headed by Dr M. Dixon, working at Cambridge on the actions of war gases on enzymes. When the team was disbanded, he was appointed to a lectureship in the Department of Biochemistry at the University of Cambridge and continued there until the move to Babraham in 1959.

Greville's main contributions were in the field of mitochondrial metabolism and the action of "uncoupling", drugs. His first biochemical studies were carried out in collaboration with F. Dickens and dealt with sugar conversions and breakdown in embryonic, tumour and adult normal tissues. In 1933 he began, with E. C. Dodds, an investigation of the metabolic stimulation produced by dinitrophenol, and that led on to a study of "uncoupling", drugs that formed the subject of his $\mathrm{PhD}$ thesis and became an interest that continued throughout the rest of his life. In the early 1950 s improved methods made possible tho preparation of mitochondria and more direct investigation of their metabolic activities. In collaboration with A. L. Lehninger, Greville showed that both $\mathrm{D}$ and $\mathrm{L}-\beta$-hydroxybutyrate undergo oxidation in mitochondria although the L-isomer was thought to be the "naturally occurring" form. The initial paths of oxidation of the two forms were found to be different, but it seemed that the $\mathrm{D}$-form also occurred naturally and played a part in ketone body and fatty acid metabolism.

In 1955 Greville and D. M. Needham showed that dinitrophenol accelerates the ATPase activity of both myosin and mitochondria and, from 1956, Greville began a collaboration with J. B. Chappell on mitochondrial swelling. They established that the swelling induced by a variety of agents, for example phosphate, thyroxino and calcium ions, was dependent on respiration and a supply of energy. After moving to Babraham in 1959, Greville continued to work on the biochemistry and morphology of mitochondria: Important studies were made of the influence of the composition of the suspending medium on the properties of these organelles and the mechanism by which they accumulate divalent metal ions. In collaboration with E. A. Munn, he isolated a new protein, for which the name calliphorin has been proposed, from mitochondria of the flight muscles of Calliphora erythracephala. Calliphorin has been purified to a single component and, together with related proteins, seems to be an important storage substance fairly widely distributed among the insect orders.

Everyone who has known or worked with Greville pays tribute to the immonse care and patience he exercised in his experimental work and the meticulous repetition used to ensure the accuracy of his observations. He spent a large part of his time helping other people with their research work, but was so self-effacing that many of theso contributions went unacknowledged. His long experience and critical attitude made him an invaluable source of information and in recent years he wrote many noteworthy reviews on mitochondrial biochemistry. An endeavour to which he recently devoted much time and care has been his co-editorship with P. N. Campbell of Essays in Biochemistry on behalf of the Biochemical Society. Authors contributing essays have been somewhat staggered to find that the Editor had checked every reference in lists frequently running to several hundred. At the time of his death, Greville was actively working on the sixth volume of this immensely successful series which is widely read for both pleasure and profit by advanced students and established workers in biochemistry.

Greville worked in a field in which there has been much controversy and moved among workers between whom deep and sometimes bitter disagreements had arisen. His balanced viewpoint here was highly regarded throughout tho scientific world. It is characteristic of his modesty and humour that when asked to scrutinize Mitchell's chemiosmotic hypothesis of respiratory chain and photosynthetic phosphorylation he introduced this as follows:

"The present writer when asked for a bird's eye appraisal of the Mitchell hypothosis felt that tho wrong phylum had been selected, and he offers instead a worm's eve scrutiny. His chief qualifications are that he is completely uncommitted and likely to bo psychologically satisfactory, since he is on excellent terms with those of the protagonists whom he happens to know."

\section{Dr I. A. Galloway}

IAN Galloway, director of the Animal Virus Research Institute at Pirbright in Surrey from 1939 to 1963 , died suddenly on December 22, 1969. He had been the leading figure in foot and mouth disease research in Britain for many years and was responsible for the major develop. ment of the laboratory at Pirbright and for the research programme which has given it its high international reputation in the field of foot and mouth disease.

Galloway was born in Edinburgh in 1900 and educated at George Heriot's School and the Royal (Dick) School of Veterinary Studies, obtaining his membership of the Royal College of Veterinary Surgeons in 1922 and his BSc the following year. His early training in research was at the Institut Pasteur, where he entered the service of Professor Levaditi. Galloway returned to England in 1926 to work at the National Institute for Medical Research at Hampstead on behalf of the Foot and Mouth Disease Researeh Committee. He was at Hampstead until 1939, when it was decided to appoint a scientific superintendent to the research station operated by the committec at Pirbright. Galloway remained at Pirbright for twenty-four years, during which he transformed the research station from a small field unit into a well equipped institute for virological research.

Galloway's contribution must be seen against the enormous changes in virological research which occurred during his career. In the early 1920s much effort was devoted to the search for experimental animals to avoid expensive experimentation in the natural hosts. Galloway's first publication recorded the pathogenicity of foot and mouth disease virus for the rabbit, a host which, although susceptible, was never destined to supplant the guinea-pig in this field. In Paris Galloway had become interested in the problem of the size and physical charac teristics of the virus; at Hampstead he and W. A.J. Elford began studies of virus size based on ultrafiltration analysis and later on ultracentrifugation. Their findings, which gave values of 8-12 $\mathrm{nm}$ by filtration and $20 \mathrm{~nm}$ by centrifugation, were not widely different from those determined twenty or more years later by more refined techniques.

The facilities at Pirbright in 1939 were a challenge to Galloway, allowing him to scale up his work and make use of the farm animal instead of the guinea-pig. He insisted that, if results of value were to be obtained (for example) in vaccination experiments, adequate numbers of cattle should be omployed to give statistically significant results and, stimulated by him, methods for accurate assay of the virus and for the estimation of immunogenic potency of vaccines were developed during the $1940 \mathrm{~s}$. Comparison of vaccines of different strains within one general immunological type brought to light hitherto unsuspected differences. Papers from the institute published in 1949 showed the importance of subtype differences in immunization programmes, and this work has influenced the practical application of foot and mouth disease vaccines all over the world.

By his personal contacts overseas, Galloway stimulated an interest in dealing with foot and mouth disease in underdeveloped countries, first of all by surveying the strains of virus that were present. This work led to the discovery of three new types in Africa in the late 1940s and a further type in Asia in 1955. The survey work established by Galloway became so obviously valuable that its continuance was guaranteed by the establishment at 